\title{
Letter to the Editor: Comments on Rotz (2018)
}

\author{
Mike Scarsbrook and Jeremy Hill ${ }^{1}$ \\ Fonterra Research \& Development Centre, Private Bag 11029, Palmerston North 4442, New Zealand
}

There is international acceptance, supported by multilateral agreements, of the need to reduce anthropogenic sources of greenhouse gases (GHG). Dairy production systems are significant contributors to these GHG emissions, and emission reduction is a critical challenge for the dairy industry. Robust measurement of GHG emissions is fundamental to this challenge and to improving management of dairy supply chains around the world.

In a recent paper in the Journal of Dairy Science, Rotz (2018) provides a timely and valuable review of the more important models and methodologies used to evaluate GHG emissions from dairy farms. The review provides useful methodological detail that supplements guidance in major international guidelines produced by the Livestock Environmental Assessment and Performance (LEAP) Partnership (FAO, 2016; IDF, 2010). As a result, the review will be of significant interest to the readership of the journal.

The paper also contains a section comparing GHG footprints of several different dairy production systems. This section is poorly linked to the overall aim of the paper, as it illustrates only one approach (whole-farm modeling) and uses just one model (Integrated Farm System Model) of the 13 reviewed in Table 1. Several important issues with this comparative analysis undermine the overall value of the paper and may lead to inappropriate interpretation by the journal's readership.

Our overall concern is in the description of different "synthetic" farm systems as representing those of specific countries or US states. The author states (page 6676) "... these results should not be used to represent all dairy farms of the types or locations reported." Despite this, the author has linked these systems to specific locations (e.g., New Zealand vs. Pennsylvania) and highlights these as "... representative dairy farms ..." in Table 2.

A comparative analysis of different dairy farm systems from different regions of the world would be highly desirable, and much effort has gone into the development of methodologies to enable such compari-

Received June 11, 2018.

Accepted August 6, 2018.

${ }^{1}$ Corresponding author: jeremy.hill@fonterra.com sons (e.g., FAO, 2016). An important element of such a global comparison is full disclosure of methods and data sources. Rotz (2018) is unusual in that it gives no reference for the source of data used in the model, beyond that provided in Table 2. The lack of detail on data sources and specific modeling assumptions makes it difficult to assess the adequacy of methods applied and the inclusiveness of key model requirements. However, in several specific areas, the methods appear incomplete or results are inconsistent with the international literature:

1. Some methodology aspects are undefined. For example, how manure was dealt with (recycled to land or sold) and what were the sources of emissions factors?

2. There is no mention of how replacement animals have been accounted for.

3. Manure collection in the New Zealand (NZ) system relates only to the time spent in the milking shed, yet the manure emissions (Table 2) are greater (per cow) than for a winter confinement system (Ireland).

4. Direct per cow methane emissions were similar across all farm systems, yet milk production varied by almost 2-fold. Methane production is directly related to feed intake, and this also drives milk production. IPCC (2006) estimates an emission factor of $121 \mathrm{~kg}$ of $\mathrm{CH}_{4}$ per cow for North American dairy farms and $81 \mathrm{~kg}$ of $\mathrm{CH}_{4}$ per cow for NZ. This difference is not reflected in per cow methane emission estimates in Table 2.

5. Crop and pasture land direct $\mathrm{N}_{2} \mathrm{O}$ emissions are much higher for the NZ farm than for US farms (by about 3-fold) when expressed on a per cow basis. Indirect ammonia emissions from crop and pasture land are about 1.5-fold higher for NZ versus the US systems. These results are surprising given the high feed demands of US systems and their manure management practices.

6. In Figure 3, the crop and pasture land source appears much too high for grazed systems or too low for confined systems (see point 5 above). Thoma et al. (2013a) identify feed rations, enteric methane, and manure management as the 
largest components of US dairy systems' cradleto-grave carbon footprint $\left[\mathrm{kg}\right.$ of $\mathrm{CO}_{2}$ equivalents $\left(\mathbf{C O}_{2} \mathbf{e}\right) / \mathrm{kg}$ of milk consumed]. Feed accounts for around $20 \%$ of the total footprint, whereas enteric methane and manure management make up 25 and $24 \%$, respectively. In Figure 3 of Rotz (2018), it appears that emissions from crop and pasture land are very low for confined systems, despite the animals producing large amounts of milk from feed generated on this land.

7. Thoma et al. (2013b) provide a comprehensive assessment of cradle-to-farm gate carbon footprints for US dairy systems. The productionweighted national average at the farm gate was $1.23 \mathrm{~kg}$ of $\mathrm{CO}_{2} \mathrm{e} / \mathrm{kg}$ of fat- and protein-corrected milk. Rotz (2018) reports values of 0.75, 0.98, and $1.04 \mathrm{~kg}$ of $\mathrm{CO}_{2} \mathrm{e} / \mathrm{kg}$ of ECM for the $3 \mathrm{US}$ systems. These estimates are well below the US average, suggesting that they are not representative.

It is our opinion that the comparison of production systems presented in Rotz (2018) is of limited value and may contain significant errors in estimates and assumptions. We recommend a thorough check be made of the life cycle analysis data. At least, the sources of data and underlying assumptions need to be made explicit. At present, it would not be possible for other practitioners to confidently replicate the comparisons made in this paper.

Furthermore, we recommend that references to specific countries or US states be disregarded by readers. The comparison of GHG footprints from New Zealand, Ireland, and 3 US states was not the objective of the paper, and the data and methods used do not appear appropriate to such a comparison and we consider there to be a very high risk of misrepresentation of results (e.g., Table 2 and Figure 3) by readers, as well as undesirable confusion regarding the assessment of GHG footprints of dairy systems.

\section{REFERENCES}

FAO. 2016. Environmental performance of large ruminant supply chains: Guidelines for assessment. Livestock Environmental Assessment and Performance Partnership. Food and Agriculture Organization of the United Nations (FAO), Rome, Italy.

IDF. 2010. IDF guide to life cycle assessment and life cycle management: A common carbon footprint methodology for the global dairy sector. International Dairy Federation (IDF), Brussels, Belgium. https://store.fil-idf.org/product/a-common-carbon -footprint-approach-for-the-dairy-sector-the-idf-guide-to-standard -life-cycle-assessment-methodology/. Accessed June 5, 2018.

IPCC. 2006. Chapter 10: Emissions from livestock and manure management. Guidelines for National Greenhouse Gas Inventories. Volume 4: Agriculture, Forestry and Other Land Use. Intergovernmental Panel on Climate Change. Accessed June 5, 2018. http:/ /www.ipcc-nggip.iges.or.jp/public/2006gl/pdf/4_Volume4/V4_10 _Ch10_Livestock.pdf.

Rotz, C. A. 2018. Symposium review: Modeling greenhouse gas emissions from dairy farms. J. Dairy Sci. 101:6675-6690. https://doi .org/10.3168/jds.2017-13272.

Thoma, G., J. Popp, D. Nutter, D. Shonnard, R. Ulrich, M. Matlock, D. S. Kim, Z. Neiderman, N. Kemper, C. East, and F. Adom. 2013a. Greenhouse gas emissions from milk production and consumption in the United States: A cradle-to-grave life cycle assessment circa 2008. Int. Dairy J. 31:S3-S14. https://doi.org/10.1016/ j.idairyj.2012.08.013.

Thoma, G., J. Popp, D. Shonnard, D. Nutter, M. Matlock, R. Ulrich, W. Kellogg, D. S. Kim, Z. Neiderman, N. Kemper, F. Adom, and C. East. 2013b. Regional analysis of greenhouse gas emissions from USA dairy farms: A cradle to farm-gate assessment of the American dairy industry circa 2008. Int. Dairy J. 31:S29-S40. https:// doi.org/10.1016/j.idairyj.2012.09.010. 